\title{
Do biogeographic parameters matter? Plant species richness and distribution of macrophytes in relation to area and isolation of ponds in NW Polish agricultural landscape
}

\author{
Beata Bosiacka $\cdot$ Paweł Pieńkowski
}

Received: 25 October 2010/Accepted: 10 August 2011/Published online: 30 August 2011

(C) The Author(s) 2011. This article is published with open access at Springerlink.com

\begin{abstract}
Effects of pond size and isolation on total vascular plant species richness and number of obligate wetland species were compared. Subsequently, the potential for the presence of spatial patterns in wetland species distribution among ponds in an agricultural landscape was explored. Relationships between species richness and two main biogeographic parameters were analysed using simple and multiple linearised regression models. Spatial patterns were looked for by means of analyses carried out with the R CRAN software (join-count statistics). Simple regression analyses performed on the regional scale $(n=50)$ revealed the significance of the effect of pond size only ( $r=0.46$ for total plant species richness and $r=0.28$ for wetland species richness vs. pond area). Further analyses conducted on the local scale identified the best multiple regression models in the largest pond cluster $(n=20)$; the
\end{abstract}

Guest editors: D. Boix, B. Oertli, R. Céréghino, T. Kalettka, J. Biggs \& A. P. Hull / Pond Research and Management in Europe - Proceedings of the 4th conference of the European Pond Conservation Network (Berlin 2010)

B. Bosiacka $(\square)$

Department of Plant Taxonomy and Phytogeography,

University of Szczecin, Szczecin, Poland

e-mail: bebos@univ.szczecin.pl

P. Pieńkowski

Department of Environmental Protection and Development, West Pomeranian University of

Technology, Szczecin, Poland models showed statistical significance of relationships between the species richness and both independent variables $(r=0.80$ for total plant species richness and $r=0.70$ for wetland species richness vs. pond area and isolation, including mean distance to the nearest ten ponds). Spatial analyses were performed for 26 obligate wetland species selected from 149 species recorded in all the 50 ponds. Exploratory spatial data analysis revealed the presence of significant positive spatial autocorrelation in the distribution of 8 species. In such cases, it is possible to reject the random distribution hypothesis, which justifies exploration of spatial regimes. In practice, correct spatial model specifications may have implications for predicting species occurrences under changing environmental conditions, e.g. changes in the number of ponds.

Keywords Temporary and permanent ponds . Biodiversity $\cdot$ Macrophyte distribution - Spatial autocorrelation

\section{Introduction}

Small, isolated wetlands are habitat islands which differ from true islands in, among other ways, a higher density and hence higher migration potential of the organisms they support. In reality, those wetlands are not truly isolated. In addition to hydrological connectivity via the groundwater, there 
is biotic connectivity provided by the migrating organisms. The extent of spatial isolation is a function of both wetland density and their distribution pattern (Leibowitz, 2003; Angeler \& AlvarezCobelas, 2005).

Species accumulation in individual wetlands is a result of gradual accretion of migrants, whereas dispersal potential of organisms depends on dispersal strategy and the nature of the surrounding matrix (Murphy \& Lovett-Doust, 2004). The habitat size may additionally affect colonisation, as it is a surrogate of habitat heterogeneity, which in turn directly affects the probability of a species' presence. However, this paradigm of the theory of island biogeography does not always hold true for small, isolated wetlands. Their specific features resulting from, among other things, differences in hydroperiod and the frequent absence of fish-keystone organisms in the trophic structure-contribute to the disproportionately high regional biodiversity of those ecosystems (Oertli et al., 2002; Williams et al., 2004; De Meester et al., 2005; Edvardsen \& Økland, 2006 Scheffer et al., 2006; Davies et al., 2008; Herault \& Thoen, 2009).

Although small, isolated wetlands fit well the basic tenet of the theory of metapopulations, the fit is provided mainly by animals. Spatial dynamics of plants is modified by their ability to escape in time (seed bank) and limited ability to escape in space (passive dispersal). In reality, most plant species do not seem to function as metapopulations (Bullock et al., 2002; Freckleton \& Watkinson, 2002; Murphy \& Lovett-Doust, 2004). Regional dynamics of plant species populations in small, isolated wetlands can be viewed in the light of other theories, e.g. the 'patchy populations theory', where there is a single population distributed among suitable habitats in a region; dispersal among sites is very high (Harrison \& Taylor, 1997) and the 'remnant populations theory' which assumes no, or extremely little, migration among sites and the ability of species to survive unfavourable conditions (Eriksson, 2000).

In the context of landscape species dynamics, despite the potentially high importance of interspecific interactions and random colonisation, biotic connectivity patterns may strongly affect the species composition of assemblages inhabiting isolated habitats (Cain et al., 2000; Bullock et al., 2002; Cottenie $\&$ De Meester, 2004).
Depending on the spatial structure of discrete habitat patches in the landscape and life-history traits of individual species inhabiting small, isolated wetlands, populations of those species may exhibit various patterns of regional dynamics. To elucidate those patterns, it is necessary to undertake both longterm observations of the seed bank and studies on, very difficult to directly determine, migration potential of individual plant species.

In this work, we analysed effects of two major biogeographic parameters, habitat size and isolation, on plant species richness in small temporary and permanent wetlands in the agricultural landscape. Further analyses of wetland species distribution among ponds served as a starting point to address the question whether macrophytes differ in migration potential. We tested three hypotheses: (H1) a larger pond size promotes a higher plant species richness; (H2) a higher pond isolation limits plant species richness; (H3) distribution of wetland species among ponds is non-random, i.e., the presence of a species in one pond increases the probability of the species occurring in the neighbouring pond.

\section{Materials and methods}

Study area and survey of flora

The study was carried out in the agricultural landscape of one of the most intensely cultivated regions in NW Poland, the Szczecin Hills $\left(53^{\circ} 17^{\prime}-\right.$ $53^{\circ} 29^{\prime} \mathrm{N}, 14^{\circ} 23^{\prime}-14^{\circ} 27^{\prime} \mathrm{E}$ ) (Fig. 1).

The Szczecin Hills emerged from glacitectonically perturbed Quaternary formations. Their surface is composed of morainic clays with local accumulations of sand. Arable lands, forests, and surface waters cover about $65 \%, 11 \%$, and less than $0.1 \%$ of the area, respectively. Midfield ponds constitute the major type of lentic waterbodies. Since the late 19 th to the second half of the 20th century, about $66 \%$ of such wetlands have disappeared from the area (Pieńkowski, 2003).

A total of 50 ponds (32 permanent and 18 temporary waterbodies) were surveyed on two visits: one in early July and the other in mid-September 2004. All vascular plant species were recorded within the outer boundary of the ponds. The data were collected from the total area of each pond until no 


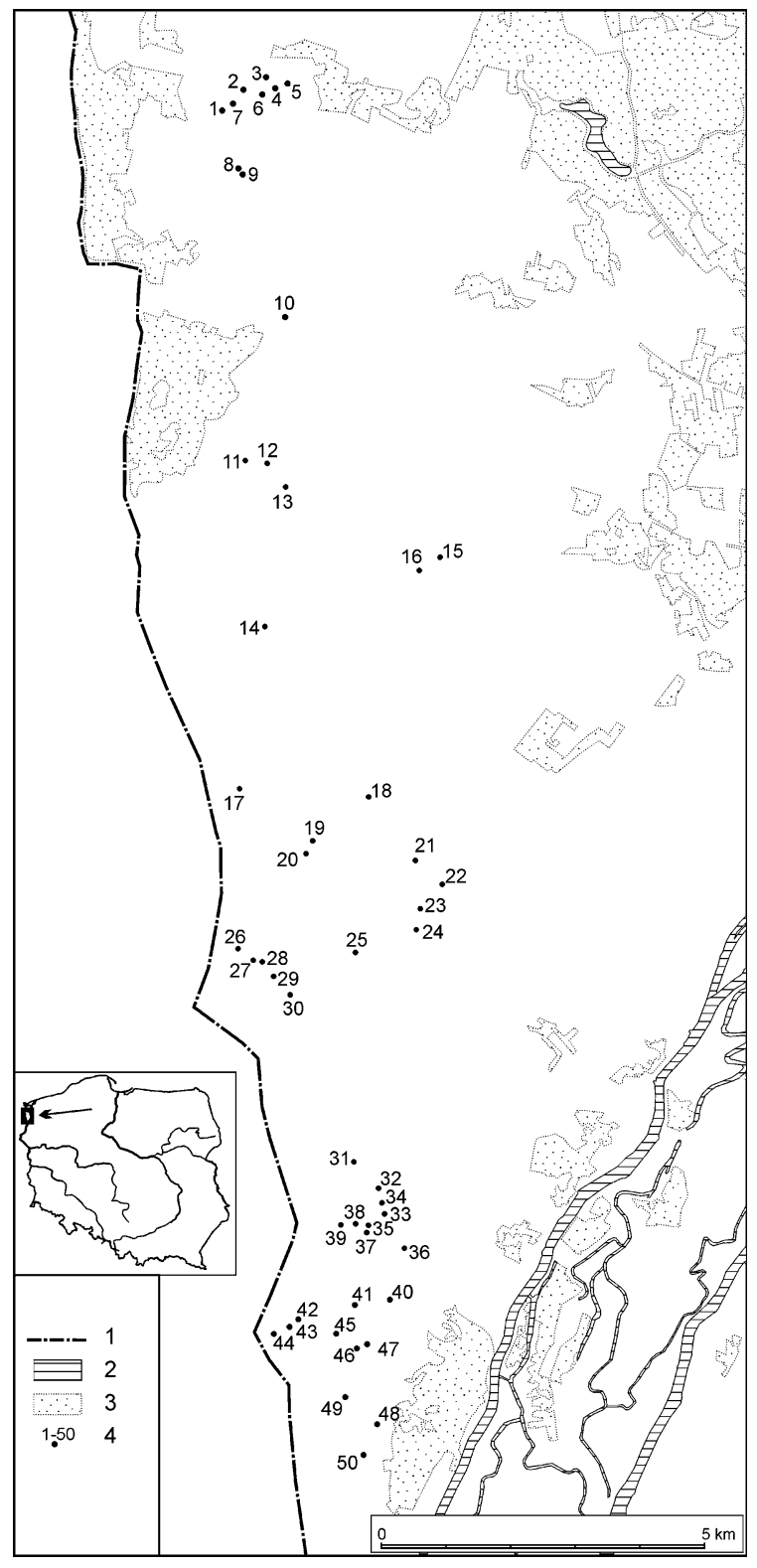

Fig. 1 Study area: 1 border of Poland, 2 rivers and lakes, 3 forest, 4 localisation and numbers of ponds

additional plant species was found. The surveys of aquatic vegetation were conducted by wading and using, in deeper water, a grapnel equipped with a 2.5 m-long telescopic handle.

All the water bodies surveyed were directly surrounded by cultivated fields or fallow land. No pond was located in river floodplain: none was accessed by livestock or surrounded by close belts of trees. The ponds were eutrophic: the mean $\mathrm{PO}_{4}{ }^{3-}$,
$\mathrm{NO}_{3}{ }^{-}$, and $\mathrm{NH}_{4}{ }^{+}$concentrations were 1.9, 2.3, and $1.1 \mathrm{mg} / \mathrm{l}$, respectively.

The outer boundary of the ponds was determined by the upper level of the winter water level, readily discernible from the distribution of wetland plants. In this study, the outer boundary was usually convergent with the cultivated land boundary. The pond total area, understood as the water surface plus the marginal zone, ranged from 0.01 to 1.2 ha (mean of $0.12 \mathrm{ha}$ ). The water surface area during the period of study ranged from 0 to 0.3 ha (mean of 0.04 ha).

\section{Data analysis}

Relationships between plant species richness and two main biogeographic parameters (pond size and isolation) were explored using simple and multiple linearised regression models. Values of the depended and independent variables were $\log _{10}$-transformed. Effects of pond size and isolation were tested on the total vascular plant species number and the number of obligate wetland species. The models included three indices of isolation: dist1, distance to the nearest pond; dist5, mean distance to the nearest five ponds; and dist10, mean distance to the nearest ten ponds.

Spatial analyses involved only the obligate wetland species, as a correct analysis of this type relies on, among other things, inclusion of all species sites within the space surveyed for detecting spatial relationships in those species' distributions. In practice, this means examination of all the discrete habitat patches of individual species. This work was based on the assumption that within the radius of spatial analyses in the area of study, the highest probability of a species's presence only in ponds is associated with obligate wetland species, i.e., aquatic (submerged and floating-leaved) plants and emergent rush plants of the class Phragmitetea only.

Spatial autocorrelation in distribution of individual obligate wetland species among the ponds was explored with the joincount.test routine of R CRAN software (The R Foundation, 2007). The presence/ absence pattern of a species may be considered analogous to that of a mixed-up chess board, with B (black) for species presence and W (white) for species absence. Statistics based on binary random variables $(1=\mathrm{B}, 0=\mathrm{W})$ can then be calculated to determine whether the patterns of $\mathrm{Bs}$ and Ws are 
random or whether they show some sort of clustering (Cliff \& Ord, 1981):

$$
\begin{aligned}
& \mathrm{BB}=\frac{1}{2} \sum_{i=1}^{n} \sum_{j=1}^{n}{ }_{i \neq j} w_{i j} x_{i} x_{j} \\
& \mathrm{BW}=\frac{1}{2} \sum_{i=1}^{n} \sum_{j=1}^{n} i \neq j \text { w } w_{i j}\left(x_{i}-x_{j}\right)^{2} \\
& \mathrm{WW}=\frac{1}{2} S_{0}-(\mathrm{BB}+\mathrm{BW}) \\
& S_{0}=\sum_{i=1}^{n} \sum_{j=1}^{n} i \neq j
\end{aligned}
$$

where $w_{i j}$, weight (Euclidean distance) between site $i$ and site $j ; x_{i}$, value of the binary random variable at site $i(1=$ present, $0=$ absent $)$.

The statistics BB and WW refer to positive spatial autocorrelation, BW representing negative autocorrelation. At the confidence level most commonly used in such analyses, $P \leq 0.05$ allows acceptance of the hypothesis of spatial autocorrelation. The higher the values of $\mathrm{BB}$ and $\mathrm{WW}$ relative to the values predicted by random distribution, the stronger the positive spatial autocorrelation in the distribution of the elements analysed. In this study, this means a higher probability of a species' presence among neighbouring ponds.

\section{Results}

The 50 ponds surveyed were found to support a total of 149 vascular plant species (the species number ranged from 9 to 37 in individual wetlands), including 43 obligate wetland species (the species number ranged from 2 to 16 in individual wetlands). The group of obligate wetland species included 8 species of submerged plants, 7 species of floating-leaved plants, and 28 species of emergent, rush-like plants of the class Phragmitetea.

A total of 17 obligate wetland macrophytes occurred sporadically in the ponds, at 1 or 2 sites only (e.g. Ranunculus trichophyllus, Butomus umbellatus, Elodea canadensis, Nuphar lutea, Nymphaea alba, Potamogeton acutifolius, P. berchtoldii, Stratiotes aloides). Analyses of spatial patterns were conducted for the distribution of remaining 26 obligate wetland species (see the list in Table 3) found in more ponds $(n>2)$.
Species richness versus pond area and isolation

The simple regression models including all the ponds showed the wetland surface area to be positively correlated with the dependent variables; the wetland size explained 21 and $8 \%$ of variation in the total species richness and in the number of obligate wetland species, respectively (H1 validated). Analyses of relationships between the number of species and the degree of isolation yielded weak negative correlations, non-significant at the 0.95 confidence level. The multiple regression analyses showed the best model to explain $24 \%$ of variance in the total species richness, including pond area and dist 10 (Table 1; Fig. 2A).

Effects of the two biogeographic parameters on the species richness were analysed also on a local scale, within individual pond clusters. Table 2 reports only those results obtained for two clusters grouping the number of ponds sufficient for multiple regression $(n \geq 10)$. The analyses performed within the largest pond cluster $(n=20)$ showed a high and moderate correlations between the dependent and independent variables. The pond size explained 45 and $28 \%$ of variance in the total species richness and in the number of wetland species, respectively (H1 validated), whereas isolation explained the proportion of variance (27-33\%) which was similar in both cases (H2 validated). In the best multiple regression models, including dist10, the two independent variables explained 64 and $49 \%$ of variance in the total species richness and in the number of wetland species, respectively (Table 2; Fig. 2B).

Analyses of wetland species distribution among ponds

To test the hypothesis of non-random distribution of obligate wetland species among the midfield ponds (H3), spatial autocorrelation analyses was performed to answer the question whether the presence of a species in one pond increased the probability of its occurring in the neighbouring one.

Analyses of spatial autocorrelation in the distribution of macrophytes among the ponds were run using three radii, starting from $2481 \mathrm{~m}$ (the radius along which each pond was connected to its nearest neighbour) and increasing the radius, twice, by $1000 \mathrm{~m}$ (to $4481 \mathrm{~m}$ ). Table 3 shows only values of the BB 


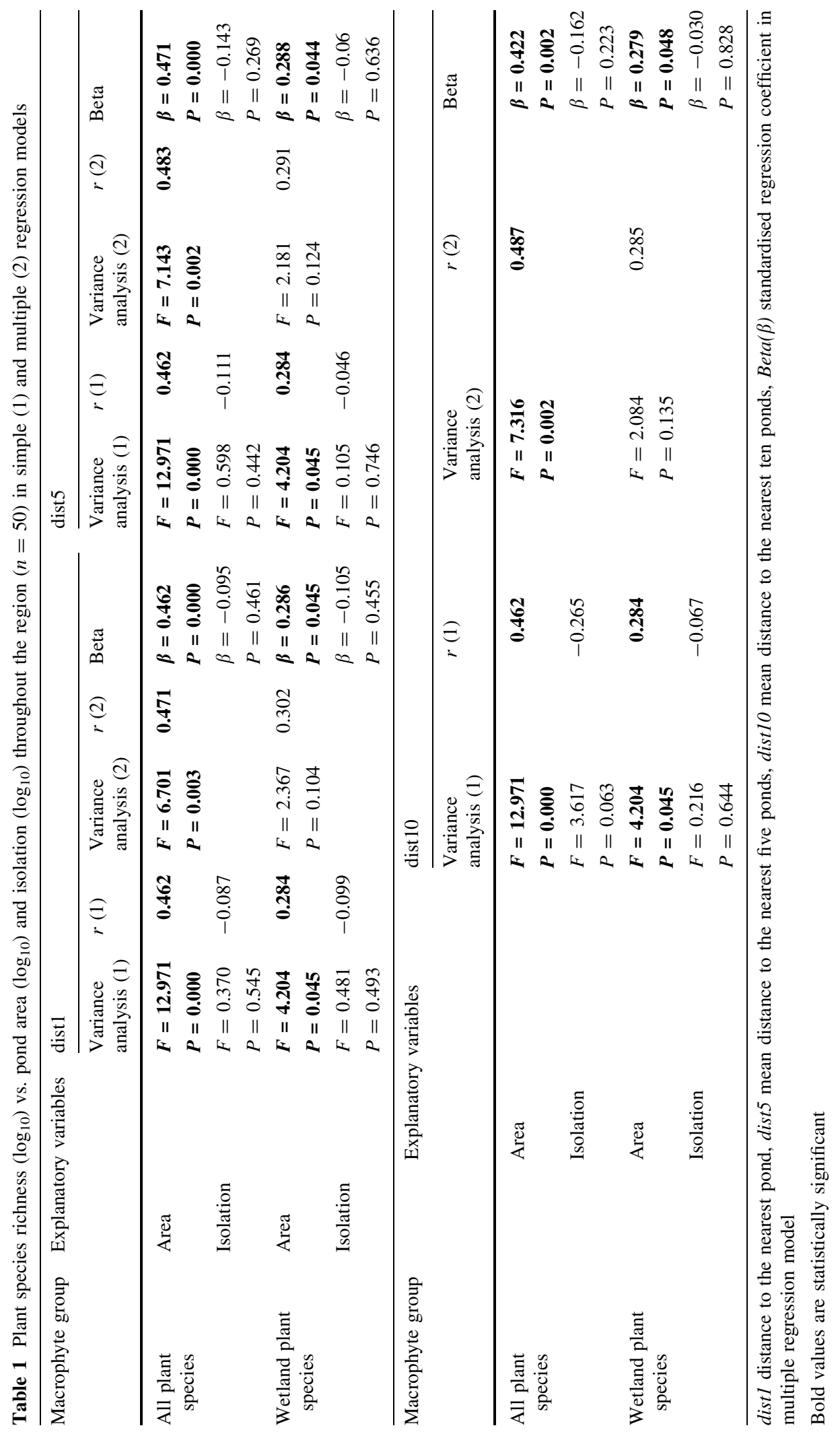




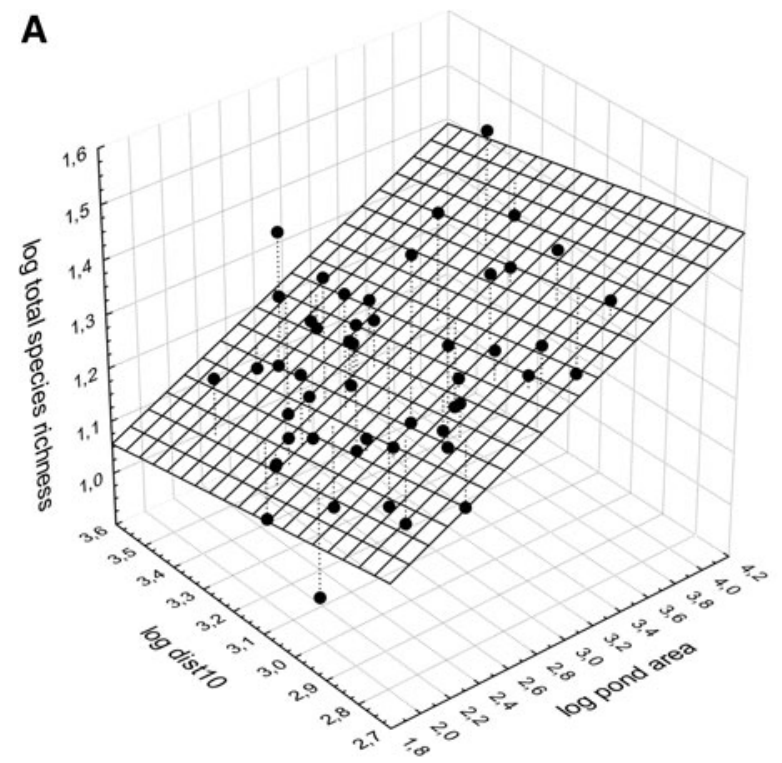

Fig. 2 Multiple regression models: A total plant species richness $\left(\log _{10}\right)$ vs. pond area $\left(\log _{10}\right)$ and isolation $\left(\log _{10}\right)$ throughout the region $(n=50, r=0.49)$; $\mathbf{B}$ wetland species

statistics corresponding to positive autocorrelation in distribution of the species. H3 was accepted $(P<$ $0.05)$ with respect to eight species, including four dispersed mainly by wind (Calamagrostis canescens, Phalaris arundinacea, Phragmites australis, and Typha latifolia) and four dispersed mainly by birds (Alisma plantago-aquatica, Ceratophyllum submersum, Carex elata, and Oenanthe aquatica; while the first two species are adapted for dispersal via water, the subsequent two have no special adaptations, but when present in isolated waterbodies, animals can be assumed to be the only vectors of heavier propagules).

\section{Discussion}

Due to the alarming rate at which small wetlands are disappearing, and because they play an important role in maintaining regional biodiversity, activities aimed at protection and regeneration of those wetlands and at creation of new ponds are gaining in popularity (Oertli et al., 2009). Such activities should take into account both local habitat conditions and the landscape context, i.e. patterns of wetland distribution and the nature of the surrounding matrix, in connection with dispersal potential of organisms (Davies et al., 2004; Murphy \& Lovett-Doust, 2004; Herault \& Thoen, 2009).

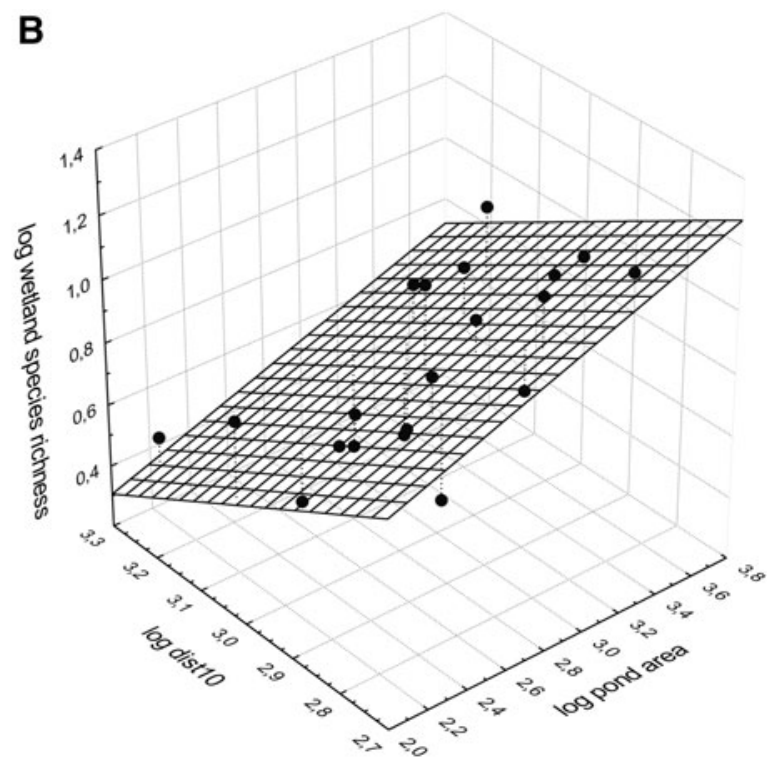

richness $\left(\log _{10}\right)$ vs. pond area $\left(\log _{10}\right)$ and isolation $\left(\log _{10}\right)$ within cluster No. $2(n=20, r=0.70)$, including mean distance to the nearest ten ponds

The focus of this work was to analyse effects of pond size and isolation on plant species richness and distribution of obligate wetland species. Midfield ponds are the major type of surface waters in the area of study. They tend to be clustered in their distribution. Although the ponds surveyed are separated by drainage ditches, most of the drainage network is at present defunct. The area of study is flanked by rivers and lakes, situated at a distance of a few to several kilometres from pond clusters. Our analyses concerned the midfield ponds only. To reduce the probability of other aquatic ecosystems affecting the number and distribution of wetland species in the habitats we studied, the analyses were conducted not only on a regional scale, but also on a local scale: within individual pond clusters and within a limited radius of spatial connections.

The regional-scale analyses showed only the pond size to significantly influence the plant species richness. However, similar analyses conducted on the local scale showed strong effects of both size and isolation of a wetland on species richness in the largest pond cluster. The necessity to carry out localscale studies is demonstrated, in addition to methodological aspects (among others, a possibility to include all, or at least most, suitable habitats), by a limited landscape dynamics of plants. Even if 


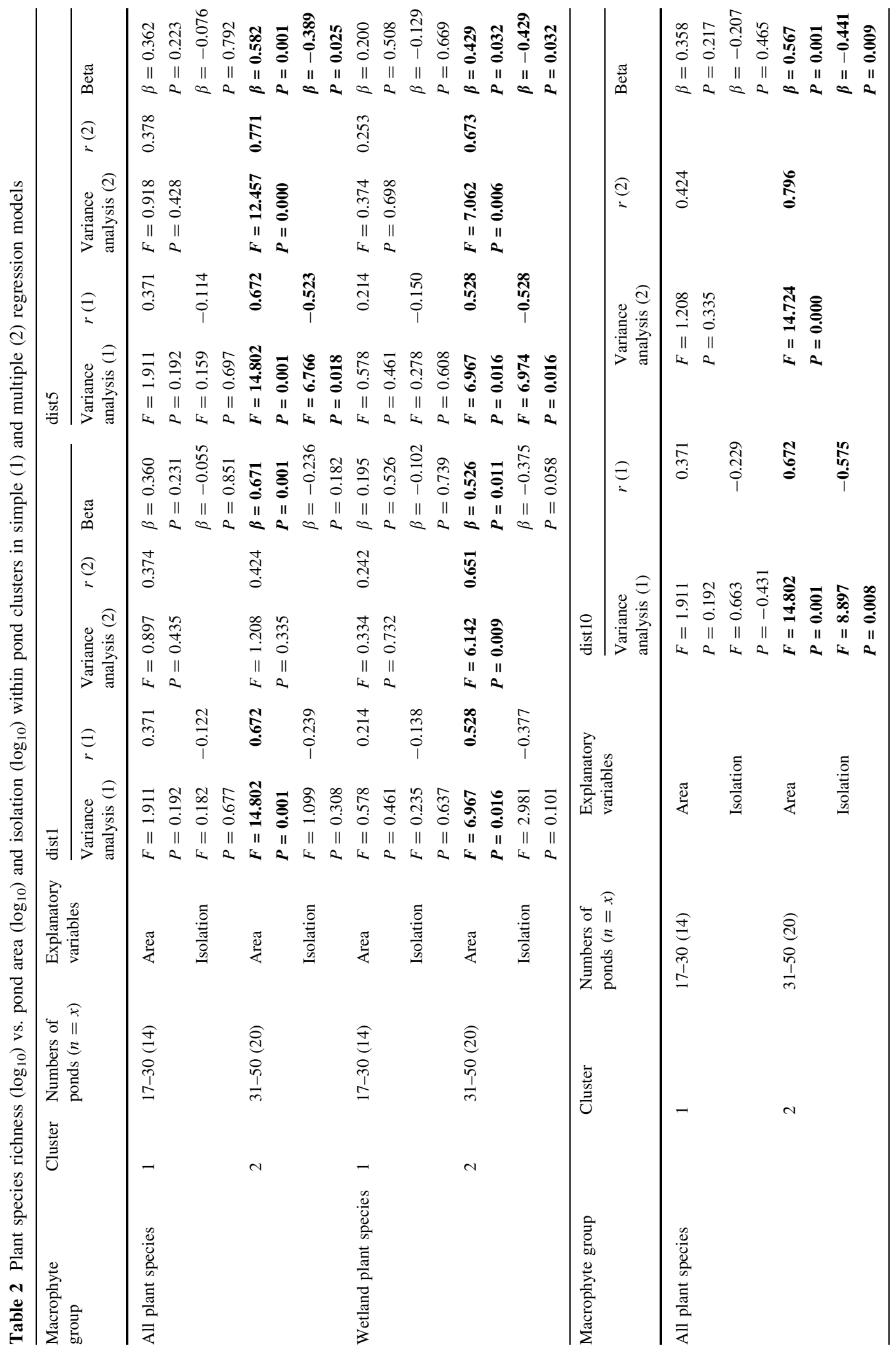


propagules are dispersed over long distances by birds, the transport often results in colonisation being successful on a local scale only (Bullock et al., 2002; Figuerola \& Green, 2002).

Some studies on relationships between biogeographic variables and species richness of permanent and temporary ponds stress a statistically significant, albeit weak, effect of habitat size on the number of vascular plant species, the effect explaining, e.g. 7\% (Oertli et al., 2002), 11\% (Brose, 2001) or 19\% (Nicolet et al., 2004) of variance in the wetland plant species richness or $15 \%$ of variance in the total plant species richness (Brose, 2001). Results of other studies suggest pond size to be a very important variable explaining a substantial part of variation in the total species richness or the number of species of some ecological groups of plants, e.g. $56-80 \%$ of variance in the total number of plant species (Møller \& Rørdam, 1985, before elimination of outliers) and a large proportion of helophyte species richness (Edvardsen \& Økland, 2006). Differences between various sets of data may, in part, stem from different methods of study, e.g. whether a study was conducted in a single landscape type or in different (e.g. open, forested) landscapes (Herault \& Thoen, 2009); how the plants were divided between ecological categories (Edvardsen \& Økland, 2006); whether permanent and temporary wetlands were combined in a study or only one wetland type was considered, e.g. in a temporary wetland, the difference in hydroperiod is an overarching factor which may even obliterate effects of pond size and isolation (Brose, 2001).

Identification of effects of isolation on species richness may, too, largely depend on the methodology adopted, for instance on whether the species richness is determined in all the wetlands or in their selected types, or on isolation indicators being used. The frequent lack of significance is explained by random dispersal of plants and seed longevity which may counteract the isolation effect (Møller \& Rørdam, 1985; Brose, 2001). However, some studies have demonstrated the between-wetland distance, in association with biodiversity of individual habitat islands, to significantly affect the biota on a local or regional scale. For example, Møller \& Rørdam (1985) found the plant species richness in ponds to be positively correlated with pond density, while Linton \& Goulder (2003) demonstrated a high plant species richness in ponds to be positively correlated 
Table 3 Summary of joincount.test for BB statistics

\begin{tabular}{|c|c|c|c|c|c|}
\hline Species & $n$ & $r(\mathrm{~m})$ & BB statistics & Expectation & $P$ value \\
\hline \multirow[t]{3}{*}{ Alisma plantago-aquatica $\mathbf{L}$. } & \multirow[t]{3}{*}{22} & 2481 & 5.319 & \multirow[t]{3}{*}{4.714} & $0.046 *$ \\
\hline & & 3481 & 4.981 & & 0.202 \\
\hline & & 4481 & 5.047 & & 0.085 \\
\hline \multirow[t]{3}{*}{ Calamagrostis canescens (Weber) Roth. } & \multirow[t]{3}{*}{4} & 2481 & 0.157 & \multirow[t]{3}{*}{0.122} & 0.365 \\
\hline & & 3481 & 0.123 & & 0.501 \\
\hline & & 4481 & 0.264 & & $0.032 *$ \\
\hline \multirow[t]{3}{*}{ Carex elata All. } & \multirow[t]{3}{*}{12} & 2481 & 1.855 & \multirow[t]{3}{*}{1.347} & $0.039 *$ \\
\hline & & 3481 & 1.756 & & $0.042 *$ \\
\hline & & 4481 & 1.609 & & $0.048^{*}$ \\
\hline \multirow[t]{3}{*}{ Carex gracilis Curtis } & \multirow[t]{3}{*}{5} & 2481 & 0.225 & \multirow[t]{3}{*}{0.204} & 0.436 \\
\hline & & 3481 & 0.351 & & 0.081 \\
\hline & & 4481 & 0.337 & & 0.080 \\
\hline \multirow[t]{3}{*}{ Carex pseudocyperus L. } & \multirow[t]{3}{*}{4} & 2481 & 0.148 & \multirow[t]{3}{*}{0.122} & 0.402 \\
\hline & & 3481 & 0.112 & & 0.522 \\
\hline & & 4481 & 0.111 & & 0.560 \\
\hline \multirow[t]{3}{*}{ Carex riparia $\mathrm{L}$. } & \multirow[t]{3}{*}{11} & 2481 & 1.396 & \multirow[t]{3}{*}{1.122} & 0.156 \\
\hline & & 3481 & 1.139 & & 0.496 \\
\hline & & 4481 & 1.038 & & 0.667 \\
\hline \multirow[t]{3}{*}{ Carex vesicaria $\mathrm{L}$. } & \multirow[t]{3}{*}{3} & 2481 & 0.000 & \multirow[t]{3}{*}{0.061} & 0.795 \\
\hline & & 3481 & 0.000 & & 0.843 \\
\hline & & 4481 & 0.032 & & 0.756 \\
\hline \multirow[t]{3}{*}{ Ceratophyllum submersum $\mathbf{L}$. } & \multirow[t]{3}{*}{11} & 2481 & 2.059 & 1.122 & $0.000 *$ \\
\hline & & 3481 & 1.943 & & $0.000 *$ \\
\hline & & 4481 & 1.678 & & $0.000 *$ \\
\hline Glyceria fluitans (L.) R. Br. & 10 & 2481 & 1.116 & 0.918 & 0.215 \\
\hline & & 3481 & 0.890 & & 0.555 \\
\hline & & 4481 & 0.891 & & 0.559 \\
\hline Hottonia palustris $\mathrm{L}$. & 5 & 2481 & 0.188 & 0.204 & 0.549 \\
\hline & & 3481 & 0.213 & & 0.472 \\
\hline & & 4481 & 0.242 & & 0.334 \\
\hline Iris pseudacorus $\mathrm{L}$. & 19 & 2481 & 3.599 & 3.489 & 0.390 \\
\hline & & 3481 & 3.554 & & 0.423 \\
\hline & & 4481 & 3.684 & & 0.198 \\
\hline Lemna minor $\mathrm{L}$. & 23 & 2481 & 5.529 & 5.163 & 0.197 \\
\hline & & 3481 & 5.442 & & 0.195 \\
\hline & & 4481 & 5.361 & & 0.264 \\
\hline Lemna trisulca $\mathrm{L}$. & 12 & 2481 & 1.256 & 1.346 & 0.623 \\
\hline & & 3481 & 1.234 & & 0.687 \\
\hline & & 4481 & 1.289 & & 0.607 \\
\hline Lysimachia thyrsiflora L. & 3 & 2481 & 0.000 & 0.061 & 0.795 \\
\hline & & 3481 & 0.000 & & 0.843 \\
\hline & & 4481 & 0.044 & & 0.634 \\
\hline Oenanthe aquatica (L.) Poir. & 33 & 2481 & 11.980 & 10.775 & $0.003 *$ \\
\hline & & 3481 & 11.563 & & $0.004 *$ \\
\hline & & 4481 & 11.582 & & $0.004 *$ \\
\hline
\end{tabular}


Table 3 continued

\begin{tabular}{|c|c|c|c|c|c|}
\hline Species & $n$ & $r(\mathrm{~m})$ & BB statistics & Expectation & $P$ value \\
\hline \multirow[t]{3}{*}{ Phalaris arundinacea $\mathrm{L}$. } & \multirow[t]{3}{*}{40} & 2481 & 16.126 & \multirow[t]{3}{*}{15.918} & 0.283 \\
\hline & & 3481 & 16.301 & & $0.042 *$ \\
\hline & & 4481 & 16.413 & & $\mathbf{0 . 0 3 4} *$ \\
\hline \multirow[t]{3}{*}{ Phragmites australis (Cav.) Stend. } & \multirow[t]{3}{*}{24} & 2481 & 7.187 & \multirow[t]{3}{*}{5.632} & $0.000 *$ \\
\hline & & 3481 & 7.353 & & $0.000 *$ \\
\hline & & 4481 & 6.615 & & $0.000 *$ \\
\hline \multirow[t]{3}{*}{ Potamogeton natans L. } & \multirow[t]{3}{*}{5} & 2481 & 0.153 & \multirow[t]{3}{*}{0.204} & 0.652 \\
\hline & & 3481 & 0.124 & & 0.776 \\
\hline & & 4481 & 0.147 & & 0.726 \\
\hline \multirow[t]{3}{*}{ Rorippa amphibia (L.) Besser } & \multirow[t]{3}{*}{20} & 2481 & 4.269 & \multirow[t]{3}{*}{3.877} & 0.167 \\
\hline & & 3481 & 3.882 & & 0.494 \\
\hline & & 4481 & 3.843 & & 0.542 \\
\hline \multirow[t]{3}{*}{ Schoenoplectus lacustris (L.) Palla. } & \multirow[t]{3}{*}{4} & 2481 & 0.053 & \multirow[t]{3}{*}{0.122} & 0.751 \\
\hline & & 3481 & 0.052 & & 0.799 \\
\hline & & 4481 & 0.097 & & 0.665 \\
\hline \multirow[t]{3}{*}{ Scutellaria galericulata L. } & \multirow[t]{3}{*}{5} & 2481 & 0.271 & \multirow[t]{3}{*}{0.204} & 0.303 \\
\hline & & 3481 & 0.213 & & 0.484 \\
\hline & & 4481 & 0.244 & & 0.343 \\
\hline \multirow[t]{3}{*}{ Sium latifolium $\mathrm{L}$. } & \multirow[t]{3}{*}{3} & 2481 & 0.000 & \multirow[t]{3}{*}{0.061} & 0.795 \\
\hline & & 3481 & 0.000 & & 0.845 \\
\hline & & 4481 & 0.000 & & 0.891 \\
\hline \multirow[t]{3}{*}{ Sparganium erectum L. s. str. } & \multirow[t]{3}{*}{22} & 2481 & 4.295 & \multirow[t]{3}{*}{4.714} & 0.839 \\
\hline & & 3481 & 4.553 & & 0.684 \\
\hline & & 4481 & 4.642 & & 0.614 \\
\hline \multirow[t]{3}{*}{ Spirodela polyrhiza (L.) Schleid. } & \multirow[t]{3}{*}{4} & 2481 & 0.073 & \multirow[t]{3}{*}{0.122} & 0.685 \\
\hline & & 3481 & 0.052 & & 0.813 \\
\hline & & 4481 & 0.098 & & 0.661 \\
\hline \multirow[t]{3}{*}{ Typha angustifolia L. } & \multirow[t]{3}{*}{3} & 2481 & 0.000 & 0.061 & 0.795 \\
\hline & & 3481 & 0.091 & & 0.309 \\
\hline & & 4481 & 0.086 & & 0.324 \\
\hline Typha latifolia $\mathbf{L}$. & 27 & 2481 & 7.585 & 7.163 & 0.173 \\
\hline & & 3481 & 7.913 & & $0.012 *$ \\
\hline & & 4481 & 7.732 & & $0.041 *$ \\
\hline
\end{tabular}

In bold-species with statistically significant positive spatial autocorrelation in the distribution among the ponds $(* P \leq 0.05)$ $n$ number of ponds supporting individual species, $r$ radius of search for spatial autocorrelation

with a higher number of species in the neighbouring water bodies. Our approach, in turn, showed a significant negative effect of pond isolation on the number of species, at least on local scale, and spatial autocorrelation in the distribution of $31 \%$ of the macrophytes analysed. Brose (2001), who studied similar relationships with other methods, demonstrated isolation to have produced adverse effects on
$19 \%$ of the wetland species analysed. In such cases, the random spatial distribution hypothesis can be rejected, which makes it possible to study spatial regimes. The actual dispersal strategy does not seem to be crucial, because the groups analysed contained species adapted to dispersal by wind, water, and animals as well as those lacking any special adaptations. 
It is only with respect to those species adapted to dispersal by wind that an explanation of the spatial limitation in their distribution can be sought: spatial patterns may be a result of a short radius of primary dispersion. Nevertheless, those species can be successful colonisers thanks to, among others, a high number of propagules produced. Of the five such species recorded in this study, four were spatially autocorrelated in their distribution. On the other hand, should isolation effects be different in species dispersed by animals (mainly birds), important may be the factors which are difficult to be directly pinpointed, e.g. propagule survival during endozoochoric transport or tightness of adhesion during epizoochoric travel. Regardless of transportation mode, however, dispersal success may be eventually modified by competitive ability revealed during colonisation, e.g. vegetative propagules versus generative propagules (Barrat-Segretain, 1996 and references therein).

Results of studies on biodiversity of ponds demonstrate the need for protection of both large and small waterbodies. On the one hand, the studies reveal a higher biodiversity in a group of small ponds compared to single wetlands of a comparable size, but - on the other-large ponds can harbour species missing in the smaller ponds (Oertli et al., 2002; Williams et al., 2004). The correlation, not overly strong, between the pond size and the number of plant species, revealed by this and other studies points to deviations from the size-species richness paradigm of the island biogeography theory (Oertli et al., 2002; Brose, 2001; Nicolet et al., 2004). Another paradigm of the theory, addressing effects of isolation on the number of species, can hold true in ponds, but relevant studies are methodologically difficult. Results of this study, however, show a possibility of even a high negative correlation between isolation and the number of species, at least on a local scale. Smaller distances between ponds may be advantageous also for the regional dynamics of those species showing spatial autocorrelation in their distribution: even at random colonisation of a few ponds over a large area, the efficiency of dispersal may be high due to non-random colonisation of neighbouring ponds close by.

In practice, differences in the degree of isolation of ponds as well as differences in their size may contribute to an increasing beta diversity of those habitats. Designing landscapes with dense pond clusters in the vicinity of already existing wetlands may favour faster colonisation and increased dynamics of populations of species they support. Direct or indirect data on the migration potential of such species may serve to predict their landscape succession in the face of wetland disappearance and frequent attempts at wetland reclamation. However, the data on dispersal potential of individual plant species are still very scant.

Open Access This article is distributed under the terms of the Creative Commons Attribution Noncommercial License which permits any noncommercial use, distribution, and reproduction in any medium, provided the original author(s) and source are credited.

\section{References}

Angeler, D. A. \& M. Alvarez-Cobelas, 2005. Island biogeography and landscape structure: integrating ecological concepts in a landscape perspective of anthropogenic impacts in temporary wetlands. Environmental Pollution 138: 421-425.

Barrat-Segretain, M. H., 1996. Strategies of reproduction, dispersion, and competition in river plants: a review. Vegetatio 123: 13-37.

Brose, U., 2001. Relative importance of isolation, area and habitat heterogeneity for vascular plant species richness of temporary wetlands in east-German farmland. Ecography 24: 722-730.

Bullock, J. M., I. L. Moy, R. F. Pywell, S. J. Coulson, A. M. Nolan \& H. Caswell, 2002. Plant dispersal and colonization processes at local and landscape scales. In Bullock, J. M., R. E. Kenward \& R. S. Hails (eds), Dispersal Ecology. Blackwell Publishing, Oxford: 279-302.

Cain, M. L., B. G. Miligan \& A. E. Strand, 2000. Long-distance seed dispersal in plant populations. American Journal of Botany 87(9): 1217-1227.

Cliff, A. D. \& J. K. Ord, 1981. Evaluating the percentage points of a spatial autocorrelation coefficient. Geographical Analysis 3: 51-62.

Cottenie, K. \& L. De Meester, 2004. Metacommunity structure: synergy of biotic interactions as selective agents and dispersal as fuel. Ecology 85(1): 114-119.

Davies, B. R., J. Biggs, J. T. Lee \& S. Thompson, 2004. Identifying optimum location for new ponds. Aquatic Conservation: Marine and Freshwater Ecosystems 14: 5-24.

Davies, B. R., J. Biggs, P. Williams, M. Whitfield, P. Nicolet, D. Sear, S. Bray \& S. Maund, 2008. Comparative biodiversity of aquatic habitat in the European agricultural landscape. Agriculture, Ecosystems \& Environment 125: 1-8.

De Meester, L., S. Declerck, R. Stoks, G. Louette, F. Van De Meutter, T. De Bie, E. Michels \& L. Brendonck, 2005. Ponds and pools as model systems in conservation biology, ecology and evolutionary biology. Aquatic Conservation: Marine and Freshwater Ecosystems 15: 715-725. 
Edvardsen, A. \& R. H. Økland, 2006. Variation in plant species richness in and adjacent to 64 ponds in SE Norwegian agricultural landscapes. Aquatic Botany 85: 79-81.

Eriksson, O., 2000. Functional roles of remnant plant populations in communities and ecosystems. Global Ecology and Biogeography 9: 443-449.

Figuerola, J. \& A. J. Green, 2002. Dispersal of aquatic organisms by waterbirds: a review of past research and priorities for future studies. Freshwater Biology 47: 483-494.

Freckleton, R. P. \& A. R. Watkinson, 2002. Large-scale spatial dynamics of plants: metapopulations, regional ensembles and patchy populations. Journal of Ecology 90: 419-434.

Harrison, S. \& A. D. Taylor, 1997. Empirical evidence for metapopulations. In Hanski, I. A. \& M. E. Gilpin (eds), Metapopulation Biology. Academic Press, San Diego: $27-42$.

Herault, B. \& D. Thoen, 2009. How habitat area, local and regional factors shape plant assemblages in isolated closed depressions. Acta Oecologica 35: 385-392.

Leibowitz, S. G., 2003. Isolated wetlands and their functions: an ecological perspective. Wetlands 23(3): 517-531.

Linton, S. \& R. Goulder, 2003. Species richness of aquatic macrophytes in ponds related to number of species in neighboring water bodies. Archives for Hydrobiology 157(4): 555-565.

Møller, T. R. \& C. P. Rørdam, 1985. Species numbers of vascular plants in relation to area, isolation and age of ponds in Denmark. Oikos 45: 8-16.

Murphy, H. T. \& J. Lovett-Doust, 2004. Context and connectivity in plant metapopulations and landscape mosaic: does the matrix matter? Oikos 105(1): 3-14.
Nicolet, P., J. Biggs, G. Fox, M. J. Hodson, C. Reynolds, M. Whitfield \& P. Williams, 2004. The wetland plant and macroinvertebrate assemblages of temporary ponds in England and Wales. Biological Conservation 120: 261-278.

Oertli, B., D. Auderset Joye, E. Castella, R. Juge, D. Cambin \& J.-B. Lachavanne, 2002. Does size matter? The relationship between pond area and biodiversity. Biological Conservation 104: 59-70.

Oertli, B., R. Céréghino, A. Hull \& R. Miracle, 2009. Ponds conservation: from science to practice. Hydrobiologia 634: 1-9.

Pieńkowski, P., 2003. Analysis of distribution and changes in the occurrence of ponds in the NW area of Poland. Rozprawy Akademii Rolniczej w Szczecinie 222: 1-122.

Scheffer, M., G. J. van Geest, K. Zimmer, E. Jeppesen, M. Søndergaard, M. G. Butler, M. A. Hanson, S. Declerck \& L. De Meester, 2006. Small habitat size and isolation can promote species richness: second-order effects on biodiversity in shallow lakes and ponds. Oikos 112(1): 227-231.

The R Foundation for Statistical Computing. R version 2.6.0., 2007. http://www.r-project.org/.

Williams, P., M. Whitfield, J. Biggs, S. Bray, G. Fox, P. Nicolet \& D. Sear, 2004. Comparative biodiversity of rivers, streams, ditches and ponds in an agricultural landscape in Southern England. Biological Conservation 115: 329-341. 